\title{
A new species of penicillate millipede from genus Mauritixenus (Diplopoda, Polyxenidae) found in Vietnam
}

\author{
C. HUYNH ${ }^{*} \&$ A. VEENSTRA \\ Cuong Huynh \& Anneke Veenstra; Centre for Cellular and Molecular Biology (CCMB), Deakin University, 221 Burwood Hwy, \\ Burwood, Melbourne, Australia 3125 \\ *Corresponding author. E-mail: cuong.huynh@deakin.edu.au
}

\begin{abstract}
Genus Mauritixenus Verhoeff, 1939 comprises a group of penicillate millipedes found only in Mascarene Islands, Madagascar and West Africa. The characteristics of this genus are 13 pairs of legs, 8 ommatidia, labrum with apical granular structure and tarsus 2 with a spine. There are seven described species in this genus. Penicillate millipedes were collected from Vietnam, Ninh Thuan Province, which proved to be a previously undescribed species in the genus Mauritixenus. Their distinguishing characteristics include the number of sensilla on gnathochilarium and the anterior lateral process in the claw, as well as the genetic makeup, concluded this is a new species in this genus.
\end{abstract}

Keywords: Genomic DNA, Mascarene Islands, Mauritixenus, penicillate millipedes.

\section{INTRODUCTION}

The genus Mauritixenus (Polyxenidae) was described by Verhoeff in 1939 based on a species, Mauritixenus gracilicornis Verhoeff, 1939, found on Mauritius Island. The description of this genus by Verhoeff included few taxonomic details and this resulted in uncertainty about the identification of this genus. Nguyen DuyJacquemin \& Condé (1967) defined genus Mauritixenus by the presence of eyes with eight ommatidia; antennal article VI with a group of 3-5 bacilliform sensilla, with the anterior one being the shortest; the surface of labrum has granular structures - spine setae or apical papillae in some species; tarsus 2 with a sharp spine. Six species from Mascarene Islands (Mauritius, Rodrigues and Reunion Islands), Madagascar and West Africa, were placed in this genus based on their similarity to Mauritixenus gracilicornis: Mauritixenus betschi Nguyen Duy-Jacquemin \& Condé, 1969; M. borbonicus (Condé \& Jacquemin, 1962) formerly known as Monographis borbonicus Condé \& Jacquemin, 1962 from Reunion Island; M. pauliani (Condé \& Jacquemin, 1962) formerly Monographis pauliani Condé \&
Jacquemin, 1962 from Reunion Island; M. sakalavus (Marquet \& Condé, 1950) formerly Monographis sakalavus Marquet \& Condé, 1950 from Madagascar; M. vachoni Nguyen DuyJacquemin \& Condé, 1969 and M. betschi retusus Nguyen Duy-Jacquemin \& Condé, 1969 (subspecies). Mauritixenus ninhthuanensis sp. nov., the first species of Mauritixenus from Southeast Asia - Vietnam is described below.

\section{MATERIALS AND METHODS}

Penicillate millipedes with the following characteristics: Eight ommatidia, adults with 13 pairs of legs and tarsus 2 with a spine, are expected to belong to genus Mauritixenus (Polyxenidae). These millipedes were collected from Vinh Hy Bay (11.710833N, 109.189722E, elevation $100 \mathrm{~m}$, Ninh Hai District), $40 \mathrm{~km}$ northwest from Phan Rang City, Ninh Thuan Province. Ninh Thuan Province is located on the South-Central coast of Vietnam (Fig. 1). This region has an arid climate with an annual rainfall of less than 800 millimetres (https://www.ni nhthuan.gov.vn, accessed 26 Oct 2019). 


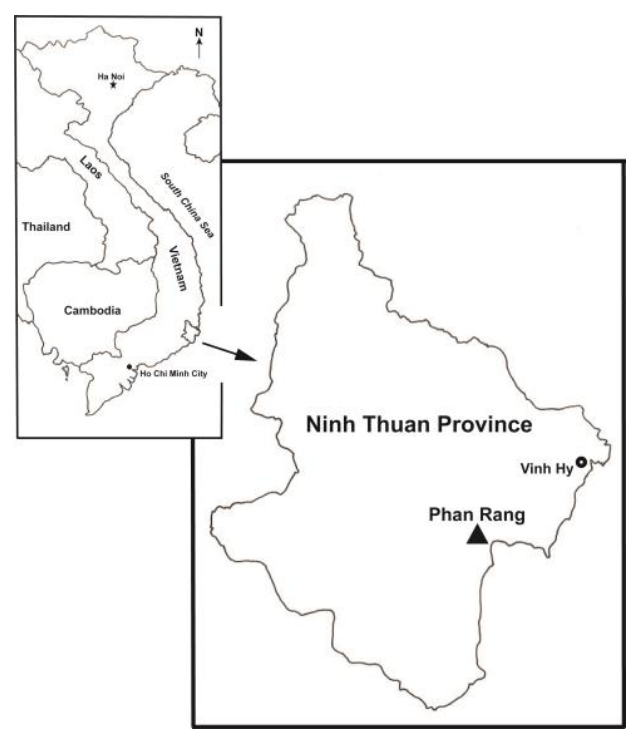

Figure 1. A map of Ninh Thuan Province, where Mauritixenus ninhthuanensis sp. nov. was collected, and the inserted map of Vietnam (Not to scale).

\section{Morphometric study}

Specimens were examined and measured using light microscopy and prepared for taxonomic illustration following the staining and slide mounting technique of Short \& Huynh (2010). This technique was used with modifications (included in the paragraph below) to permit the extraction of DNA for genetic studies. The remaining cuticles of the specimens were mounted on slides for morphometric analysis as described in Huynh \& Veenstra (2015). Scanning electron microscopy (SEM) followed the technique of Huynh \& Veenstra (2018a). Holotype and paratypes were deposited in the Queensland Museum (QMS), Brisbane, Australia.

\section{Genetic studies}

The quantity of DNA extracted from six individual Mauritixenus specimens from Ninh Thuan Province was determined using a NanoDrop 1000 Spectrophotometer (ND
1000V3.60 software) following the manufacturer's instructions. Two genes were sequenced for this study: The $18 \mathrm{~S}$ small subunit ribosomal RNA gene (primers $1 \mathrm{~F}$ and 5R, White et al. 1990) and the mitochondrial cytochrome c oxidase subunit I gene, COI (primers dgLCO1490 and dgHCO2198, Meyer 2003). Both primer sets are conserved universal primers for these gene regions and are common molecular markers used for species-level identification. The $18 \mathrm{~S}$ gene marker has been used to elucidate relationships among arthropod groups including crustaceans, insects and myriapods (Turbeville et al. 1991, Luan et al. 2005, Wesener et al. 2010, 2016). This region has also been used to help separate penicillate millipede species of the genera Lophoturus, Monographis and Phryssonotus in combination with morphological characters (Huynh \& Veenstra 2015, 2018a, $2018 b$ ). The COI region was included because it is commonly used in the Barcode of Life (2010 2019) for species identification. The polymerase chain reaction (PCR) protocol followed Huynh $\&$ Veenstra $(2018 a)$.

Representative DNA sequences from $\mathrm{Mau}$ ritixenus ninhthuanensis $\mathrm{sp}$. nov. have been deposited in GenBank (http://www.ncbi.nlm.nih.g ov), the following accession numbers for $M$. ninhthuanensis sp. nov.: MN621363 (18S) and MN621892 (COI). The accession numbers for other Mauritixenus species also used in this study: Mauritixenus gracilicornis (MN621361 for 18S and MN621890 for COI) and M. pauliani (MN621362 for 18S and MN621891 for COI). The $18 \mathrm{~S}$ and COI sequences from the new species were queried in a BLAST search (http:// www.ncbi.nlm.nih.gov) to find sequences of closely related species. All sequences from the search were aligned with sequences from the studied species using BioEdit (Hall 1999), MEGA 7 (Kumar et al. 2016) was used to generate the bootstrap maximum-likelihood tree for determining phylogenetic relationships. Numbers above branches represent bootstrap values. GenBank accession numbers for the sequences from penicillate millipede species and outgroups are listed in Table 1 (http://www.ncbi.nlm.nih.g ov, accessed 8 Aug 2019). 
Table 1. GenBank accession numbers of the partial sequences of $18 \mathrm{~S}$ and COI of Mauritixenus ninhthuanensis, other penicillate millipedes and the Outgroups were used in the study of genetic relationship.

\begin{tabular}{|c|c|c|c|c|c|}
\hline Family & Genus & Species & Location & 18S rRNA & COI \\
\hline \multirow[t]{4}{*}{ Synxenidae } & Phryssonotus & Phryssonotus australis & Australia & KY820871 & KY820869 \\
\hline & & Phryssonotus chilensis & Chile & MF592749 & MF592728 \\
\hline & & Phryssonotus novaehollandiae & Australia & KY820870 & KY820867 \\
\hline & & Phryssonotus occidentalis & Australia & KY820872 & KY820868 \\
\hline \multirow[t]{13}{*}{ Polyxenidae } & Mauritixenus & Mauritixenus gracicolus & Mauritius & MN621361 & MN621890 \\
\hline & & Mauritixenus ninhthuanensis & Vietnam & MN621363 & MN621892 \\
\hline & & Mauritixenus pauliani & Rodrigues & MN621362 & MN621891 \\
\hline & Monographis & Monographis dongnaiensis & Vietnam & KP255446 & - \\
\hline & & Monographis phuquocensis & Vietnam & MG210571 & MG279505 \\
\hline & & Monographis queenslandica & Australia & KF147166 & MG279506 \\
\hline & Polyxenus & Polyxenus fasciculatatus & Europe & AF173235 & - \\
\hline & & Polyxenus lagurus & Europe & MF592763 & - \\
\hline & & Polyxenus pugetensis & Europe & MF592764 & - \\
\hline & Unixenus & Unixenus corticolus & Australia & - & MG279507 \\
\hline & & Unixenus intragramineus & Vietnam & MG210572 & MG279508 \\
\hline & & Unixenus karajinensis & Australia & MF592754 & - \\
\hline & & Unixenus mjobergi & Australia & MF592755 & - \\
\hline \multirow[t]{3}{*}{ Lophoproctidae } & Lophoturus & Lophoturus boondallus & Australia & MG210573 & MG204536 \\
\hline & & Lophoturus molloyensis & Australia & MG210574 & MG204537 \\
\hline & & Lophoturus queenslandicus & Australia & MG210575 & MG204535 \\
\hline \multirow[t]{3}{*}{ Outgroups } & & Procyliosoma leae & Australia & FJ409955 & FJ409910 \\
\hline & & Sphaeromimus musicus & Africa & FJ409961 & - \\
\hline & & Glomeridella minima & Europe & - & JN271878 \\
\hline
\end{tabular}

\section{TAXONOMY}

\section{Subclass Penicillata Latreille, 1831 \\ Order Polyxenida Verhoeff, 1934 \\ Family Polyxenidae Lucas, 1840 \\ Genus Mauritixenus Verhoeff, 1939}

Type species. Mauritixenus gracilicornis Verhoeff, 1939
Diagnosis. Each eye 8 ommatidia; body 10 tergites, 9 pleural projections; 13 pairs of legs; 8 antennal articles, VI longest, VIII shortest with 4 sensory cones. Antennal article VI with 4 bacilliform sensilla, sensilla located in anterior position shortest than posterior ones, arranged in transverse row; surface of the labrum with apical papillae; palps of gnathochilarium well developed, lateral palp of gnathochilarium 2 times longer than the medial palp, with 16 conical sensilla; a spine on tarsus 2; coxal glands on coxae $8^{\text {th }}$ and $9^{\text {th }}$. 


\section{Mauritixenus ninhthuanensis sp. nov.}

(Figure 2)

Material examined. Type specimens. Adult male holotype (Queensland Museum registered number: QMS 110919), 4 adult female paratypes (QMS 110920-110923), 5 adult male paratypes (QMS 110924-110928) from Vietnam, Ninh Thuan Province, Vinh Hy Bay, Ninh Hai District, Phan Rang City, 11.710833 $\mathrm{N}, 109.189722 \mathrm{E}$, elevation $100 \mathrm{~m}, 8^{\text {th }}$ November 2018 (Collected by C. Huynh). All mounted slides will be cataloged and lodged in the Queensland Museum, Brisbane, Queensland, Australia.

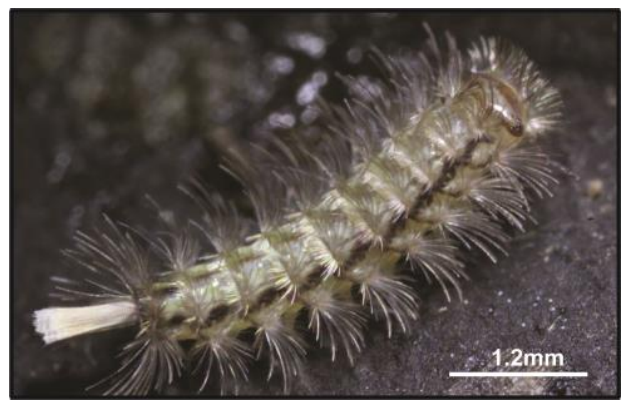

Figure 2. A live image of Mauritixenus ninhthuanensis sp. nov.

Etymology. The species is named Mauritixenus ninhthuanensis sp. nov. as this Mauritixenus species was first found in Ninh Thuan Province, Vietnam.

Diagnosis. Adults 3.0-3.8 $\mathrm{mm}$ in length, 8 ommatidia, 13 pairs of legs. Antennal article VI with a conical sensillum, 3 bacilliform sensilla and a setiform sensillum, arranged transversely; labrum with apical papillae; the telotarsus with anterior lateral process presents, posterior process longer than half the claw and setiform process is longer than the claw.

Description. Specimens are light yellowishbrown, 2 dark lateral bands contrasting with a light-yellow medial band across the body. Eye areas with dark brown and connecting each area with a brown colour band in the vertex region. Pearl white pleural trichomes, and lighter col- oured caudal bundle (Fig. 2). Holotype male body length $3.2 \mathrm{~mm}$ (Paratypes: males 3.0-3.5 $\mathrm{mm}$, females 3.4-3.8 mm). Male caudal trichome bundle narrower in width, bundle slightly longer $(0.6 \mathrm{~mm})$ than female $(0.5 \mathrm{~mm})$.

Head: Each side 8 ommatidia: 4 dorsal, 4 lateral ( 1 anterior, 2 medial and 1 posterior position). Vertex with two posterior trichome groups and a large medial gap. Each trichome group has 2 rows: anterior row, curved slightly, on an oblique angle with larger sized trichome sockets in the middle, and small sockets on both ends; posterior row with 2-6 trichome sockets, commonly 3 sockets on both sides; a narrow medial space between these 2 rows. Holotype's posterior trichome groups has 15 sockets (Left: L) and 14 sockets (Right: R) in the anterior rows; 3 sockets on both sides in the posterior rows (Figs. 3A and 3E) (Paratypes with 14-20 sockets in the anterior rows and 2-6 in the posterior rows (Fig. 6C)).

Trichobothria: Typically thin sensory hairs with narrow cylindrical funicles; trichobothria equal in socket size forming an isosceles triangle with equal distance $\boldsymbol{a b}$ and $\boldsymbol{b c}$ (Figs. 3F and 6C) (trichobothrium $\boldsymbol{a}$ located in posterior position in relation to the head capsule, trichobothrium $\boldsymbol{b}$ in lateral position, trichobothrium $\boldsymbol{c}$ in anterior position).

Antennae: Eight antennal articles, 4 sensory cones, typical characteristics of Polyxenidae. Holotype: Antennal article VI with 3 bacilliform sensilla, different lengths: Shortest, thin bacilliform sensillum located in anterior position (ta), the intermediate long thick bacilliform sensillum (Ti), and the longest thin bacilliform sensillum (tp) in the posterior position. Setiform sensillum (s) between ta and $\mathrm{Ti}$ and conical sensillum (c) in next to tp (Figs. 4A, 4C, 7A and 7C). Antennal article VII has 2 thick bacilliform sensilla, equal in length, $\mathrm{Ta}$ and $\mathrm{Tp}$, a setiform sensillum (s) between them and a conical sensillum (c) located next to Tp. (Figs. 4A, 4B, 7A and 7B). (This pattern of sensilla on the antennomere VII is commonly seen in all Mauritixenus species).

Clypeolabrum: Holotype with 11 setae along labrum's posterior margin, these setae 
being less than half the width of the labrum (Setae in paratypes ranging from 10-16 in both sexes). Labral surface with apical papillae, forming rows of large size setae along the ante- rior margin and reducing in size on posterior margin. Anterior margin of the labrum with $2+2$ lamellae (lateral lamella and lamella) on each side of median cleft (Figs. 3H, 6D and 6E).
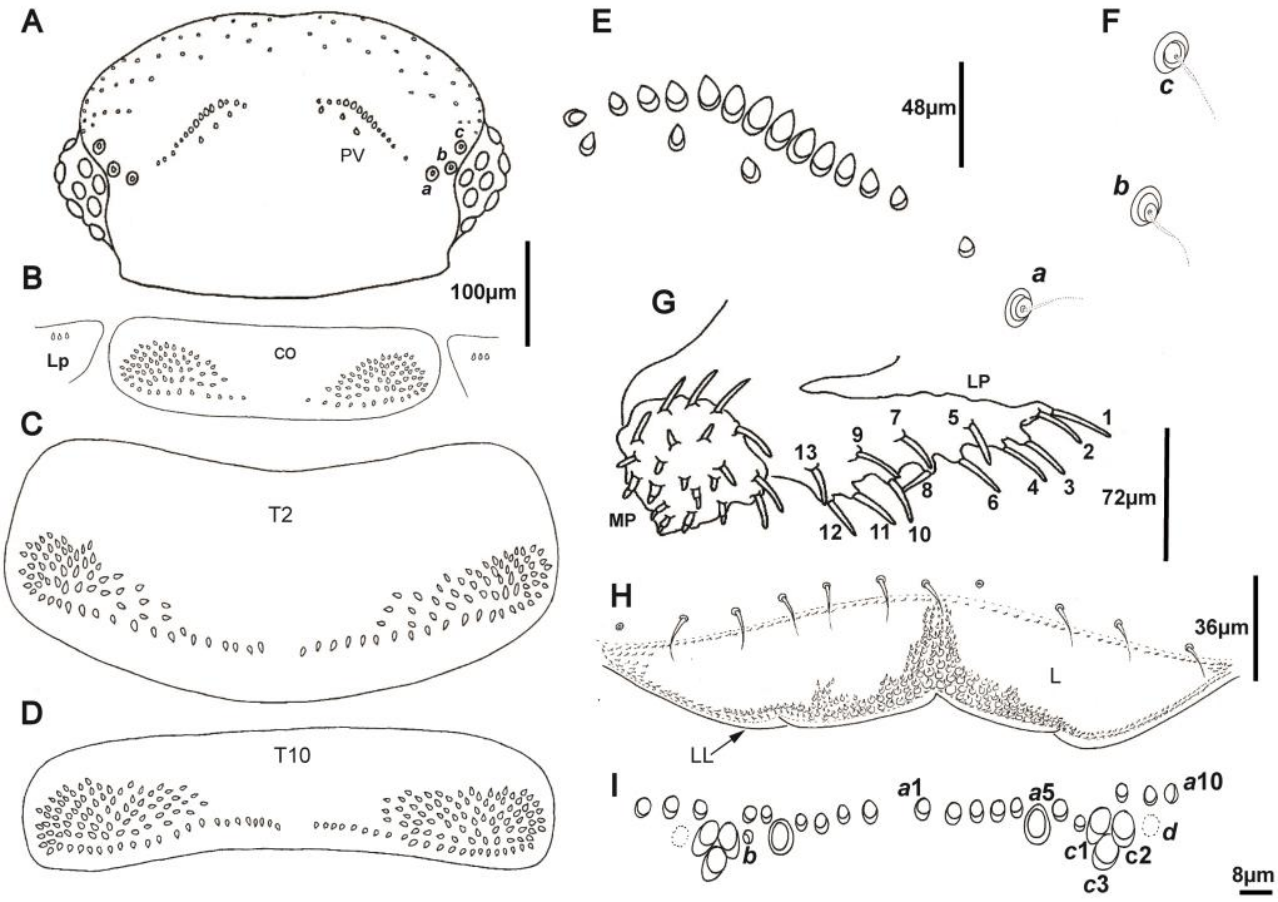

Figure 3. Holotype of Mauritixenus ninhthuanensis sp. nov. A = Head capsule, showing eye patterns with 8 ommatidia on each side, 3 trichobothrium sockets $(a, b$ and $c$ ) and 2 posterior vertex trichome sockets (pv); B = Collum (co) and the lateral protuberances (Lp) showing pattern of trichome sockets with all trichomes removed; C = Tergite 2 (T2) with trichome sockets arrangement depicted; D = Tergite 10 (T10 - last tergite) with smaller trichome sockets (A, B, C and D drawn to the same scale); $=$ Posterior vertex trichome sockets (enlarged, right hand side) $\mathrm{F}=$ Trichobothria (right hand side): trichobothrium $a$ (posterior position to the head capsule), trichobothrium $b$ (lateral position next to the eye) and trichobothrium $c$ (anterior position to the head capsule); $\mathrm{G}=$ Gnathochilarium: Lateral palp (LP) with 13 sensilla and medial palp (MP) with 21 sensilla; $\mathrm{H}=$ Clypeo-labrum: labrum with lamella (L) and lateral lamella (LL) on each side of the median cleft, labrum surface showed apical papillae, 11 setae

( 2 setae missing and only presented with the sockets) along the posterior margine of labrum; $\mathrm{I}=$ Dorsal ornamental trichome sockets: 10 trichome $a$ sockets, 1 trichome $b$ socket, 3 trichome $c$ with protruding based sockets and the circular indentation $d$.

Gnathochilarium: Lateral palp twice as long as medial palp. 13 conical sensilla on lateral palp, medial palp with 21 , same in holotype and paratypes (Figs. 3G and 6F). Trunk: 10 tergites, 9 pleural projections, and telson excluding caudal bundle.13 pairs of legs. Collum (tergite 1) with trichome sockets arranged in 2 oval shapes in the lateral position opposite each other, connected by a posterior row of trichome sockets forming a line with a gap in the middle. Holotype, trichome sockets in collum with 65 (L) and $67(\mathrm{R})$, lateral protuberances with 3 trichome sockets on each side (Fig. 3B) (Trichome sockets on collum varying in paratypes ranging from 64-83 sockets and 3-4 sockets on lateral protuberances). Tergites $2-10$, each with pleural projections located in anterolateral positions. Tergal trichome socket arrangements from tergites 2-9 
typically with 2 broad oval shapes, slightly enlarged laterally, connected with a posterior row extending toward to the centre with a large gap between these trichome sockets (Figs. 3C and 6C). Tergite 10 is the exception, with trichome sockets being smaller and denser (Fig. 3D). Trichome sockets of tergite 2 in holotype have 67 (L) and 65 (R) (Fig. 3C). Tergite 10 with 93 sockets on both sides (Fig. 3D) (In contrast, trichome sockets on tergite 2 in paratypes 66-70, whereas tergite 10 has between 91-110 trichome sockets). Legs: Leg segmentation following Manton (1956). Legs 1 and 2 without trochanter, leg 1 lacking tarsus 1 .
A

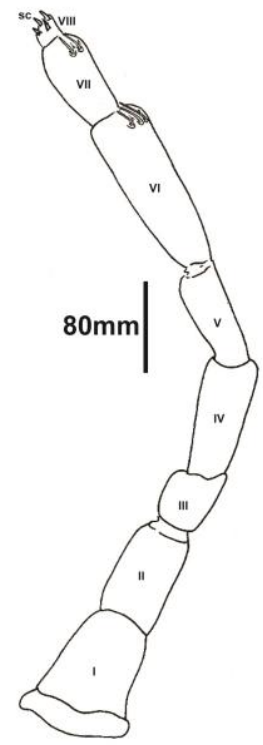

B
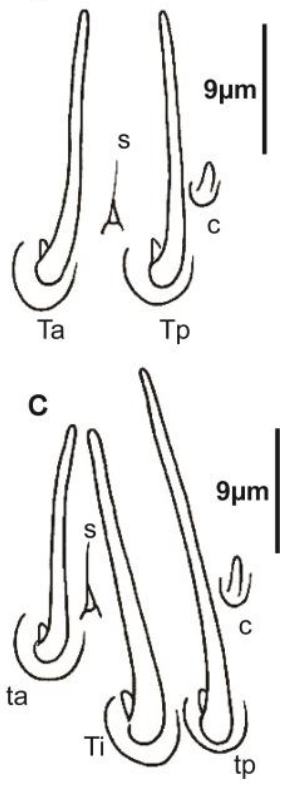

Figure 4. Holotype of Mauritixenus ninhthuanensis sp. nov. $\mathrm{A}=$ Whole antenna showed 8 article; $\mathrm{B}=$ Bacilliform sensilla (T) arrangement on article VII: Ta (Thick bacilliform sensillum located in anterior position in the sensilla arrangement on VII), Tp (posterior), s (setiform sensillum located in between $\mathrm{Ta}$ and $\mathrm{Tp}$ ) followed by c (conical sensillum located in the posterior position in the arrangement structure); $\mathrm{C}=$ Bacilliform sensilla ( $\mathrm{T}$ ) arrangement on article VI: ta (thin short bacilliform sensillum located in anterior position), Ti (Thick long bacilliform sesnillum located in the intermediate position in the structure) and tp (thin longest bacilliform sesnillum located in posterior position); s (setiform sensillum located between ta and $\mathrm{Ti}$ ) and c (conical sensillum located in the posterior position).
Chaetotaxy (setae on leg articles): coxa 1: 1 seta, coxa 2: 2 setae, coxae 3-13: 2-4 setae; prefemur, post-femur and tibia with a seta (sometimes with 2 setae on tibia); femur with 2 setae and tarsus 2 with a long, sharp spine (Figs. 5A and 8A). Setae on coxa, pre-femur, femur distally with the ridged bi-articulated, funicular cylindrical sensilla (Fig. 5D); setae in mid femur and tibia are similar, but smaller (Figs. 5B and 5C), tarsus 1 without seta and tarsus 2 with a long sharp spine (Figs. 5E and 8B). Posterior edge of the last sternite with 2 setae similar those present on coxa (Number of these setae vary from 2-4 in paratypes). Sex organs in male: Pair of penes present on coxa 2; 2 pairs of coxal glands on coxal plates of legs $8^{\text {th }}$ and $9^{\text {th }}$.

Telotarsus-Claw: A slender structure bearing a posterior lateral process that is longer than half the length of the claw. A small anterior lateral process and a lamella process present, anterior setiform process slightly enlarged at base and longer than the claw (Figs. 5F and 8D).

Telson: Dorsal ornamental trichome sockets arranged symmetrically on both sides of telson with 10 trichome $\boldsymbol{a}$ sockets in holotype (Paratypes with 10-17 trichomes $\boldsymbol{a}$ ), these trichome $\boldsymbol{a}$ sockets form 2 rows with small sockets above and larger sockets in a row below, the largest trichome $\boldsymbol{a}$ socket is often in position 5 (Figs. 3I). A single trichome $\boldsymbol{b}$ socket and 3 trichome $\boldsymbol{c}$ with large protruding base sockets: $\boldsymbol{c} 1, \boldsymbol{c} 2$ and $\boldsymbol{c} 3$, forming a triangular shape each side of telson. Circular indentation $\boldsymbol{d}$ apparent near the exterior side of trichomes $\boldsymbol{c}$.

Caudal bundles: Male, caudal bundle with a single bundle of uniform large trichome sockets of caudal trichomes. Female, two obvious distinguishing structures: A main dorsal structure similar to the male, but with 2 latero-sternal bundles of smaller trichome sockets of nest trichomes (Fig. 8C). Caudal trichomes 2-4 hooks. (These caudal structures are like those observed in $\mathrm{Mo}$ nographis (Huynh \& Veenstra 2013) which is classified as caudal bundle type I (Condé \& Nguyen Duy-Jacquemin 2008)).

Remarks. Mauritixenus ninhthuanensis sp. nov. is the first species from genus Mauritixenus 
(Polyxenidae) found in Vietnam which is outside the Mascarene Islands and African region. Mauritixenus ninhthuanensis characteristics are similar to most species in genus Mauritixenus in having a spine on tarsus 2, labrum with apical papillae structures and antennal article VI with three bacilliform sensilla. All these characteristics are found in a group of Mauritixenus species: Mauritixenus pauliani and M. sakalavus. Mauritixenus ninhthuanensis sp. nov. differs in body length (3.0-3.6 mm) and the number of sensilla on the gnathochilarium lateral palp (13 sensilla).

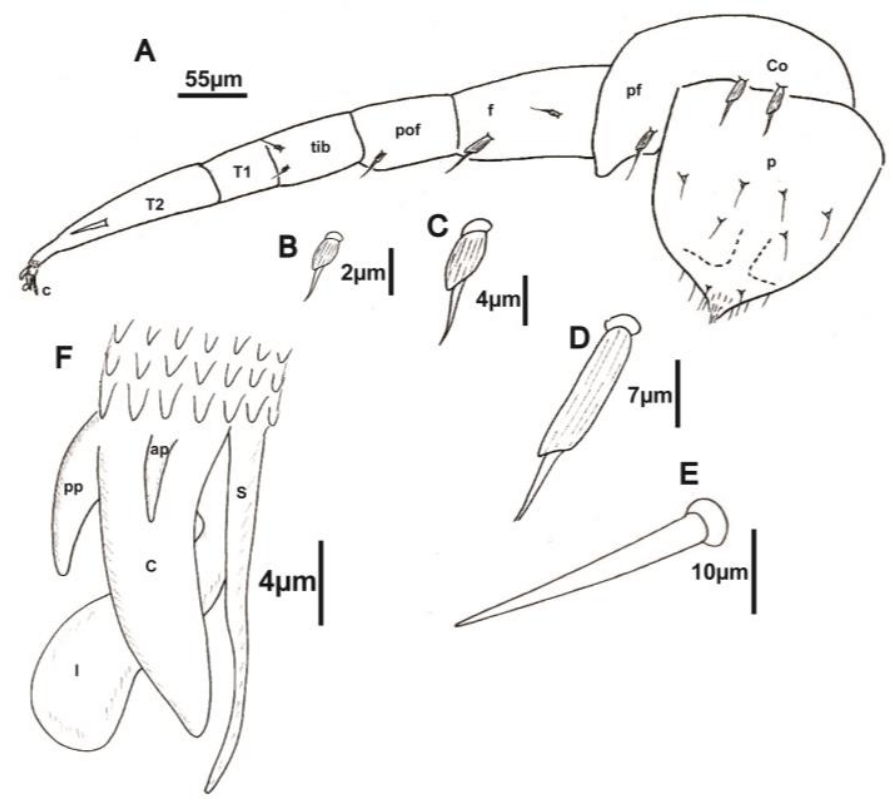

Figure 5. Holotype of Mauritixenus ninhthuanensis sp. nov. A = Leg segments and chaetotaxy (Setae on leg segments) of the second leg and penis (Co: coxa, pf: prefemur, f: femur, pof: post femur, tib: tibia, T1: tarsus 1, T2: tarsus 2 and c: claw). Three types of ridged biarticulate funicular cylindrical setae present; $\mathrm{B}=$ the smallest seta found in tibia and the mid femur; $\mathrm{C}=$ smaller seta found in post femur; $\mathrm{D}=$ normal seta found in coxa, prefemur and femur; $\mathrm{E}=\mathrm{A}$ long sharp spine on Tarsus $2 ; \mathrm{F}=$ Telotarsus with processes indicated (c: claw, ap: anterior lateral process, pp: posterior lateral process, s: setiform process and l: lamella process).

\section{Key to described species of Mauritixenus}

(Mauritixenus betschi retusus Nguyen DuyJacquemin \& Condé, 1969 was not included in this key due to inefficient characters as subadult stage).

1. Labrum with apical papillae, lateral gnathochilarium palp with

- Labrum with spine setae, lateral gnathochilarium palp with

2. 12 sensilla, Antennal article VI with 5 sensilla Mauritixenus borbonicus

- 16 sensilla, Antennal article VI with 4 sensilla .Mauritixenus gracilicornis
- 8 sensilla, Antennal article VI with 3 sensilla ..Mauritixenus sakalavus - 12 sensilla, Antennal article VI with 3 sensilla ............... ...Mauritixenus pauliani - 13 sensilla, Antennal article VI with 3 sensilla .............. Mauritixenus ninhthuanensis sp. nov.

3. 10 sensilla, Antennal article VI with 3 sensilla ...Mauritixenus vachoni

- 11 sensilla, Antennal article VI with 3 sensilla ..Mauritixenus betschi

\section{Phylogenetic Analysis}

Sequences from the new species Mauritixenus ninhthuanensis were compared with 
other penicillate millipede sequences available from GenBank (Tab. 1). The $18 \mathrm{~S}$ maximum likelihood tree generated by 1000 bootstrap rep- lications yielded a strongly supported phylogenetic tree with the bootstrap value $(>50$, shown on the nodes of the clade). The $18 \mathrm{~S}$ region of the
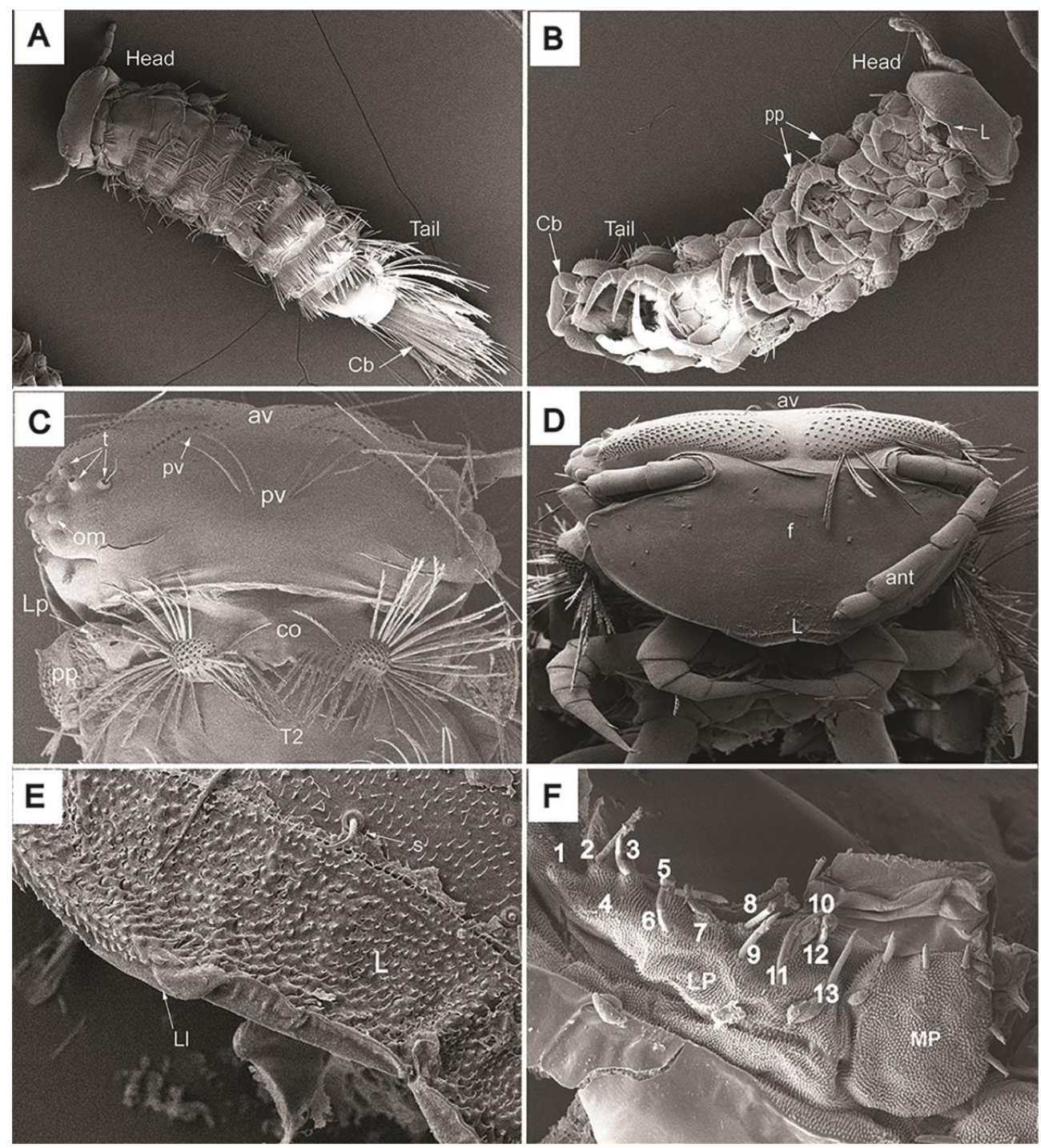

Figure 6. Mauritixenus ninhthuanensis $\mathrm{sp}$. nov. $\mathrm{A}=$ Dorsal view $(\mathrm{Cb}$ : caudal bundle); $\mathrm{B}=$ Ventral view (L: labrum, pp: pleural projections; $\mathrm{C}=$ Head capsule, collum (co) and T2 (Dorsal view, av: anterior vertex, PV: posterior vertex, pv: posterior vertex trichome group, t: trichobothria, om: ommatidia, Lp: lateral protuberances, pp: pleural projection); $\mathrm{D}=$ Head capsule and mouth part (Ventral view, f: frons, L: labrum, ant: antenna); E = Labrum surface with apical papillae (L: labrum, Ll: lateral labrum); $\mathrm{F}=$ Gnathochilarium showed lateral palp (LP) with 13 sensilla and medial palp (MP) showed few sensilla and some missing sensilla. 


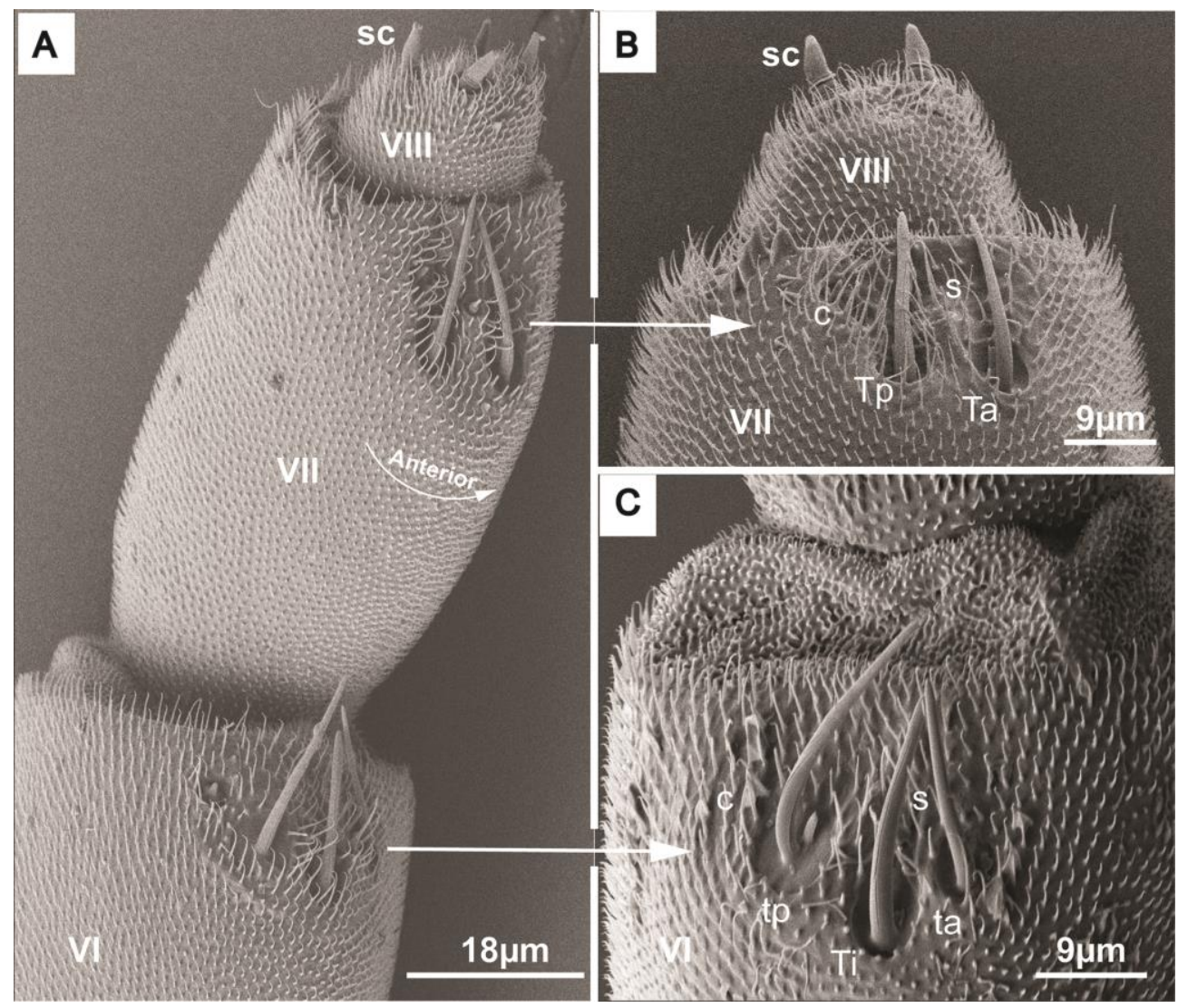

Figure 7. Mauritixenus ninhthuanensis sp. nov. $\mathrm{A}=$ Antennal articles VI, VII, VIII and sensory cones (sc) and the sensilla arrangements; B = Antennal article VII, VIII, sensory cone (sc) and sensilla on article VII (c: conical cones, Tp: thick bacilliform sensillum (posterior position), Ta: thick bacilliform sensillum (anterior position) and s: setiform sensillum); $\mathrm{C}=$ Antennal VI and its sensilla arrangement (ta: Thin short bacilliform sensillum located in anterior position, Ti: Thick long bacilliform sensillum located in the intermediate position in the structure and tp: Thin longest bacilliform sensillum located in posterior position).

3 sequences from studied species of $M$. ninhthuanensis sp. nov., M. pauliani and M. gracilicornis formed their statistically supported clades with sequences of the genus that they belong (Fig. 9A). Another bootstrap maximum likelihood tree based on a comparison of the COI region of this new species of the genus Mauritixenus also yielded a strong supported phylogenetic tree (Fig. 9B). All phylogenetic analysis indicated that this species is a new species from the genus Mauritixenus in family Polyxenidae.

\section{DISCUSSION}

The discovery of Mauritixenus ninhthuanensis in the Southeast Asian region showed that the genus Mauritixenus is not restricted to the Mascarene and African regions. Mauritixenus species have a wide distribution. In this genus, the species are characterised by a spine on tarsus 2 making it different from other genera in family Polyxenidae: Monographis Attems, 
1907 has spines on tarsus 1 and 2, it is distinctively different from Unixenus Jones, 1944, Eudigraphis Silvestri, 1948 and Saroxenus Cook, 1896 species that have a setiform seta on tarsus 2. The Vietnamese $M$. ninhthuanensis sp. nov. has characteristics similar to two Mauritixenus species - M. pauliani and M. sakalavus - all have a labrum with apical papillae, and 3 bacilliform sensilla on the antennal article VI. But they differ in the number of gnathochilarium's sensilla. The minor differences in characteristics within these species indicated little variation among species within this genus. The genetic study of $M$. ninhthuanensis sp. nov., including $M$. gracilicornis and $M$. pauliani which were collected from Mauritius and Rodrigues, showed that this is a new species according to the study of COI genes. The $18 \mathrm{~S}$ genes indicate that they belong to the genus Mauritixenus (Polyxenidae). The description of this new species will enhance the knowledge of penicillate millipedes worldwide.

Acknowledgement - Special thanks to Le family and Le Quoc Phu in Phan Rang City (Ninh Thuan Province) who helped me during the fieldwork. To Dr. Nicholas Porch, who allowed me an opportunity to join his fieldwork in Mauritius and Rodrigues Islands - It was here, that I collected Mauritixenus gracilicornis and M. pauliani for this study. To Associate Professor Jan West who helped fund for my travel. Without these people, this study would not be possible to achieve.
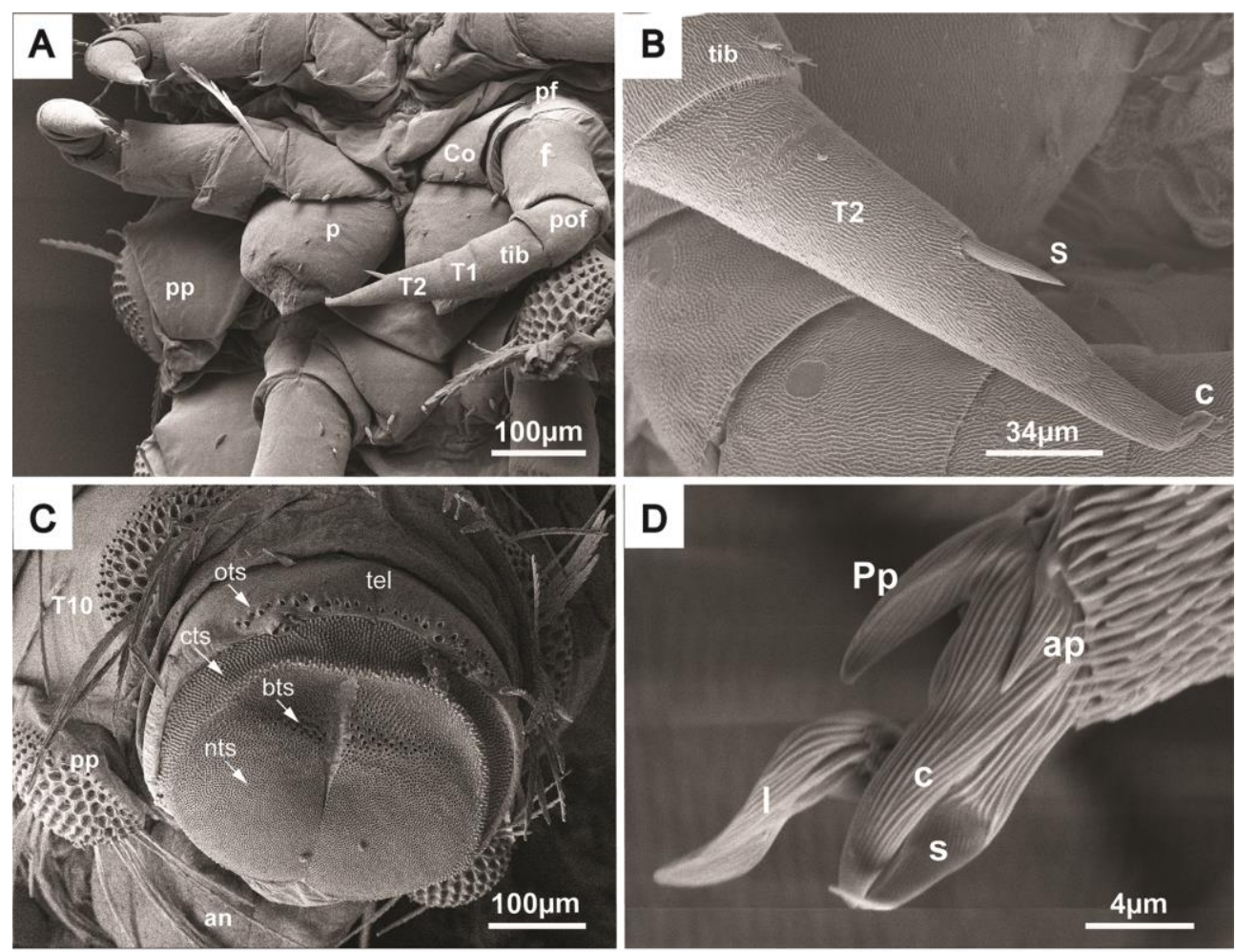

Figure 8. Mauritixenus ninhthuanensis sp. nov. A = Leg segments and chaetotaxy (Setae on leg segments) of the second leg and penis (Co: coxa, pf: pre femur, f: femur, pof: post femur, tib: tibia, T1: tarsus 1, T2: tarsus 2 and c: claw; p: penis, pp: pleural projection); B = segment of the 1st leg showed T1 and T2 with a spine (S) and claw (c); C = Caudal bundle structure showed telson (tel), ornamental trichome sockets (ots), caudal bundle trichome sockets (cts), barbate trichome sockets (bts), nest trichome sockets (nts), tergite 10 (T10), pleural projection (pp), anus (an); D = Telotarsus showed the claw (c), lamella process (l), setiform process (s), anterior lateral process (ap), posterior lateral process $(\mathrm{Pp})$. 
A.

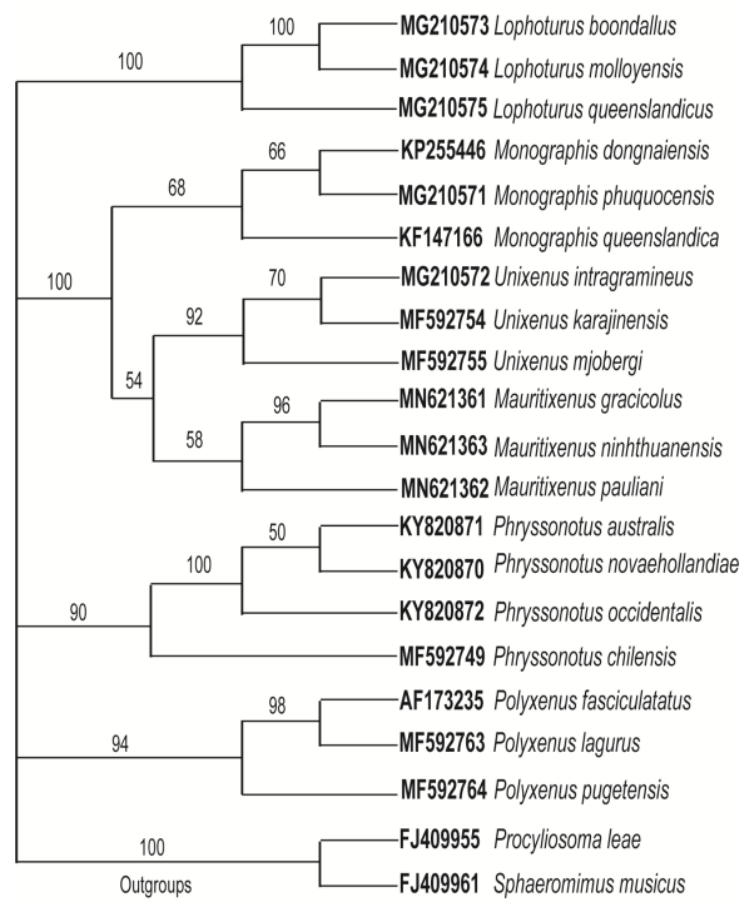

B.

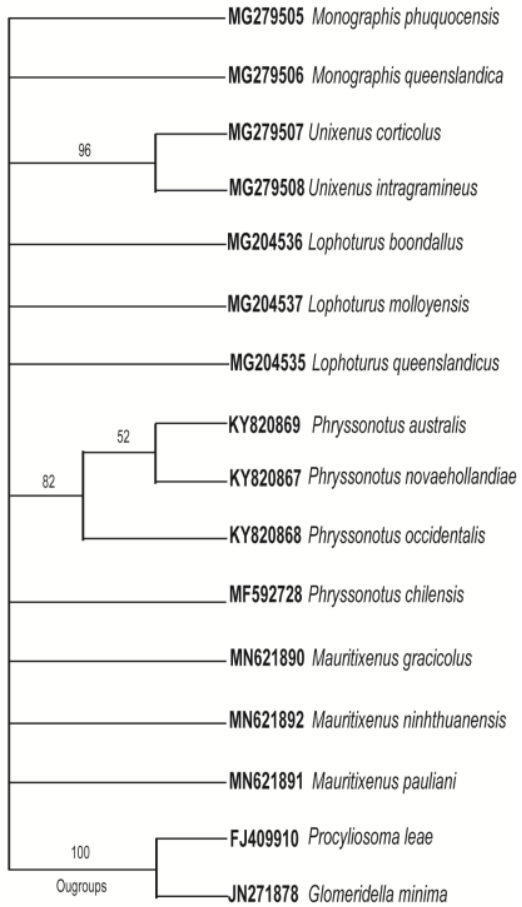

Figure 9. Molecular phylogenetic trees analysis of Mauritixenus ninhthuanensis sp. nov. with other penicillate millipedes from the GenBank (Bootstrap values $>50$ ) by maximum likelihood method. $\mathrm{A}=$ based on $18 \mathrm{~S}$ genes; $\mathrm{B}=$ based on COI gene.

\section{REFERENCES}

BARCODE OF LIFE (2010-2019): Available from URL:http://www.barcodeoflife.org [Accessed 15 October 2019]

Conde, B. \& JACQUemin, M. (1962): Dipolopodes Pénicillates de Madagascar et des Mascareignes. Revue Française d'Entomologie, 29(4): 254-285.

Conde, B. \& Nguyen Duy-Jacquemin, M. (2008): Classification actuelle des Diplopodes Pénicillates (Myriapodes) avec nouvelles définition des taxa. Bulletin de la Société Zoologique de France, 133(4): 291-302.

CooK, O.F. (1896): An American Glomeroid. Brandtia (A series of occasional papers an Diplopoda and other Arthropoda), 10: 43-45.

doi: $\underline{10.5962 / \mathrm{bhl} \text {.title. } 125177}$
HALL, T.A. (1999): BioEdit: A user-friendly biological sequence alignment editor and analysis program for Wndow 95/98/NT. Nucleic Acid Symposium Series, 41: 95-98.

Huynh, C. \& VeEnstra, A. (2013): Taxonomy and biology of a new species of Pincushion Millipede of the genus Monographis (Diplopoda: Polyxenida) from Australia. Zootaxa, 3721(6): 573588. doi: 10.11646/zootaxa.3721.6.4

HuYNH, C. \& VEENSTRA, A. (2015): Description of a new species of Penicillate Millipede from the genus Monographis (Diplopoda: Polyxenidae) found in Vietnam. Zootaxa, 3964(4): 460-474. doi: $\underline{10.11646 / \text { zootaxa.3964.4.5 }}$

Huynh, C. \& VeEnstra, A. (2018a): Two new species of Phryssonotus (Diplopoda: Synxenidae) from southern and western Australia. Australian Journal of Zoology, 65(4): 248-256. doi: 10.1071/ZO17074 
Huynh, C. \& Veenstra, A. (2018b): Two new Lophoturus species (Diplopoda, Polyxenida, Lophoproctidae) from Queensland, Australia. ZooKeys, 741: 133-154.

doi: $\underline{10.3897 / \text { zookeys.741.21814 }}$

Kumar, S., Stecher, G. \& TAmura, K. (2016): MEGA7: Molecular Evolutionary Genetic Analysis Version 7.0 for bigger datasets. Molecular Biology and Evolution, 33: 1870-1874. doi: 10.1093/molbev/msw054

Luan, Y.X., MaLlatT, J.M., XIE, R.D., YanG, Y.M. \& YIN, W.Y. (2005): The phylogenetic positions of three basal-hexapod groups (Protura, Diplura, and Collembola) based on ribosomal RNA gene sequences. Molecular Biology and Evolution, 22: 1579-1592. doi: 10.1093/molbev/msi148

LuCAS, H. (1840): Histoire Naturelle des Crustacés, des Arachnides et des Myriapodes. P. Duménil, Paris. 600 pp. doi: 10.5962/bhl.title.44485

MANTON, S.M. (1956): The Evolution of Arthropodan Locomotory Mechanisms-Part 5: The Structure, Habits and Evolution of the Pselaphognatha (Diplopoda). Journal of the Linnean Society London, 43: 153-187. doi: 10.1111/i.10963642.1957.tb02516.x

MARQueT, M.L. \& Conde, B. (1950): Contribution à la connaissance des Diplopodes Pénicillates d'Afrique et de la région madécasse. Mémoires de l'Institut Scientifique de Madagascar, série A, 4: 113-134.

MEYER, C.P. (2003): Molecular systematics of cowries (Gastropoda: Cypraeidae) and diversification patterns in the tropics. Biological Journal of the Linnean Society, 79: 401-459. doi: 10.1046/j.1095-8312.2003.00197.x

NGuyen Duy-Jacquemin, M. \& CONDE, B. (1967): Mauritixenus, genre méconnu de Diplopode Pénicillate. Bulletin du Muséum National d'Histoire Naturelle, 2e s., 39: 313-319.

NGuYen Duy-JACQUEMIN, M. \& CONDE, B. (1969): Nouveaux représentants malgaches du genre
Mauritixenus (Diplopodes penicillates). Cahiers O.R.S.T.O.M. Série Biologie, 7(4): 59-68.

ShORT, M. \& HuYNH, C. (2010): A technique for examination of diagnostic characters of penicillate millipedes. Memoirs of Queensland Museum, Nature, 55(1): 231-234.

SILVESTRI, F. (1948): Tavola sinottica dei generi dei Diplopoda Penicillata. Bollettino del Laboratorio di Entomologia Agraria, Portici, 8: 214 220.

Turbeville, J.M., Pfeifer, D.M., Field, K.G. \& RAFF, R.A. (1991): The phylogenetic status of arthropods, as inferred from 18S rRNA sequences. Molecular Biology and Evolution, 8: 669-686.

VERHOEFF, K.W. (1939): Diplopoden der Insel Mauritius und ihre zoogeographische Bedeutung. Jenaische Zeitschrift für Naturwissenschaft, 73: 37-96.

Wesener, T., Raupach, M.J. \& Sierwald, P. (2010): The origins of the giant pill-millipedes from Madagascar (Diplopoda: Sphaerotheriida: Arthroshaeridae). Molecular Phylogenetics and Evolution, 57: 1184-1193. doi: 10.1016/j.ympev.2010.08.023

Wesener, T., Voigtländer, K., DeCKer, P., OEYEN, JP. \& SPELDA, J. (2016): Barcoding of Central European Cryptops centipedes reveals large interspecific distances with ghost lineages and new species records from Germany and Austria (Chilopoda, Scolopendromorpha). ZooKeys, 564: 21-46.

doi: $10.3897 /$ zookeys.564.7535

White, T.J., Bruns, T., LeE, S. \& TAYlor, J.W. (1990): Amplification and direct sequencing of fungal ribosomal RNA genes for phylogenetics. In. InNIS, M.A., GELFAND, D.H., SNINSKY, J.J. \& White, T.J. (eds.) PCR Protocols: A Guide to Methods and Applications. Academic Press, Inc., New York, pp. 315-322. doi: $\underline{10.1016 / \mathrm{B} 978-0-12-372180-8.50042-1}$ 